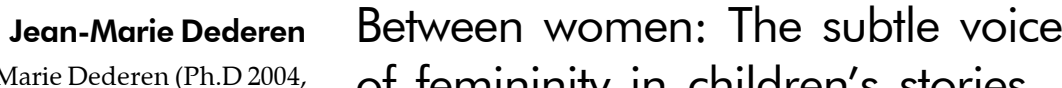 Jean-Marie Dederen (Ph.D 2004, U Johannesburg) teaches Anthropology, of femininity in children's stories
} Applied Anthropology and Archaeology at the University of Venda, Thohoyandou, South Africa. He has been involved with cultural research in the Vhembe region since 1985. E-mail: dederenj@univen.ac.za (1)

\section{Between women: The subtle voice of femininity in children's stories}

The purpose of this essay is to illustrate and explore the representation of women in a selection of eight African children's stories from Vhembe, in the Limpopo Province. The discussion is shaped primarily by the shared knowledge of the female elders who provided the narratives and participated in their analysis. The argument put forward is plain and simple: storytelling is one of many stratagems by means of which rural women — far from being passive spectators, nor willing consumers of a patriarchal world view — have created an autonomous physical and symbolic space for themselves, in opposition to the "stronger sex". By combining anthropological analysis with indigenous exegesis, it was established that some of the selected narratives reveal the voices of women's "protest", the nature of which is subtle and understated rather than rebellious or subversive. Keywords: children's stories, feminine discourse, rural women's narratives, Vhembe region, women's protest.

\begin{abstract}
Prelude
Children's stories from southern Africa reveal, on closer scrutiny, a marvellous ambiguity. They are at once aesthetic and functional; fantasy and reality. They provide light-hearted entertainment and by the same token moralise earnestly. They are neither a-temporal nor historical in any absolute sense. They express living culture and passive remembrance. They mirror social change as well as continuity. They reflect social life and comment on it.
\end{abstract}

\section{Introducing a view-from-within}

During the twenty odd years of my visits to the woodcarvers of Vhembe district, Limpopo Province, I have seen endless variations on the theme of khomba, the nubile girl. Dzikhomba sculptures depict young women in humble postures of bowing, kneeling or squatting (see Fig. 1). The artists readily acknowledged that they enjoyed carving the girls' physical beauty. When buyers inquired about the servile body 
postures, they were told that these depicted "the traditional ways for a woman to respect her husband, the lion of the house". Yet there was one producer of the khomba icon who had a different explanation, Noria Mabasa, the only female sculptor in the region.

Mabasa has created many images of young females, perhaps more than any other artist, both in clay and in wood. Many admirers of her work, including myself, have been puzzled by the presence of these images amongst her magnificent public pieces. The latter, larger sculptures celebrate the sacrifices that rural women have made towards the freedom struggle. For a long time I consoled myself with the notion that, most probably, the artist did not consider representations of servile women to be part of her more "serious" work.

One day, I found Noria carving another khomba and I inquired once more: "Why these girls, Noria?" "I have told you before, they are beautiful!" she smiled. "Yes, beautiful for men to gaze at!" I answered disapprovingly. "The problem is one. You look at this khomba like a man!" she replied. Noria then explained to me, very patiently, in what ways she thought that women's

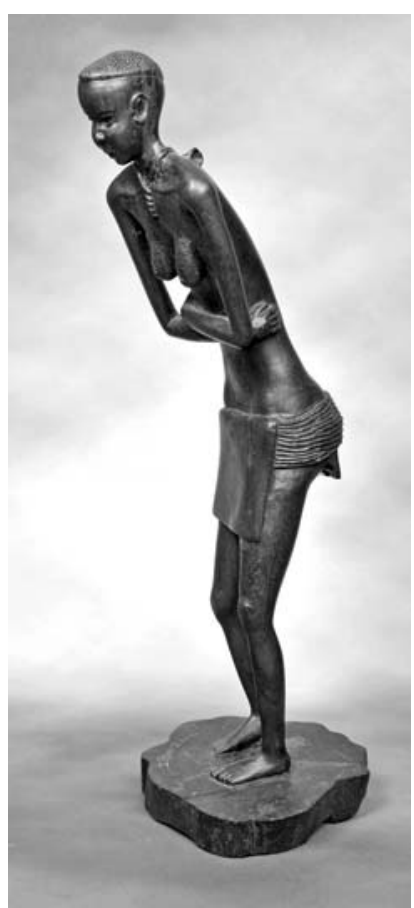

Fig. 1: Khomba: female initiate in the humble body posture of the domba initiation school. By Jafter Luvhimbi 2004 h: 600mm (author's collection). respectful greeting positions (locally known as $u$ losha, or $u$ khotha), could be called "beautiful".

Young women were trained, as part of their puberty rites, to greet their future husbands respectfully, she concurred with the male woodcarvers. However, only a man would believe that the initiation of girls was organised for his sole benefit. The prime function of these rites was to prepare the participants for motherhood. Therefore, the girls (and not their future husbands), Noria emphasized, were the main beneficiaries of the initiation. Also, I was reminded, respectful salutations were required during encounters with all kinds of people in senior positions, both male and female.

In short, Noria made me aware of the fact that the khomba sculptures, and their humble female body language, meant different things to men and women, something I had overlooked for almost a decade. As a result of discussions with the artist, and during my subsequent research on female initiation, I have come to know that khomba carvings were perceived by women as a means of honouring and celebrating womanhood; the seductive elegance of the female body; the self-discipline and selfrespect of a female adult-in-the-making; and the dignity and moral strength of a wife and mother. In addition, I have also learned that the cultural personality features of a "real" woman were meant to please the living dead (i.e. the ancestors), rather than to 
serve or to satisfy the self-importance of men. Body language, postures and decoration; didactic sculpture in the initiation school; music, songs and dance, and a host of other symbolic statements-including storytelling, as will be demonstrated shortlyconstituted a true feminine discourse, a voice of rural women.

\section{Storytelling, social conflict and gender opposition}

Even an introductory encounter with southern African storytelling will soon make the reader aware of the prominence of social tension. There are tales of aggression, enmity, envy and greed, in which orphans and other destitute protagonists are being victimised.

Elsewhere, we are told how rulers abuse the wives of their subjects; men change into predators and consume young girls; co-wives are ill-treated and spouses oppose one another; senior relatives exploit their juniors. The depiction of gender opposition, then, seems to be just one of many expressions of a much wider theme of social discord.

Some researchers argue that the omnipresence of conflict can be explained as a literary or stylistic means. Harold Scheub in his The Xhosa Ntsomi (1975) exemplifies this position in his most impressive attempt at creating a literary theory of Xhosa folklore. Iintsomi, the Xhosa folktales, Scheub (3) clarifies, should be understood as performance rather than as text. The plot is as a rule embodied by conflict and resolution, two features that are said to provide a basic structure to the narrative. Scheub (147) conceives of tension and harmony as aesthetic qualities, in addition to being aspects of social reality. Conflict/tension is defined as any kind of obstacle between the central character and what she strives for. Conflict is the essence of the plot. It causes the fragmentation of the life of the main protagonist. It can be defined also as a disturbance of the social equilibrium. It is said only to be resolved when the removal of the hindrance restores harmonious relationships between the affected members of society (Scheub 168).

The basic structure of tension and resolution, Scheub (172-73) proposes, has a distinct didactic purpose. Its presence communicates to the audience essential social values and affirms social institutions (rather than questions or undermines them). During the process of the performance, significant social relationships are being explored and proper social responses are idealized, dramatized and internalized. As a matter of fact, the performance is said to mediate the purging of anti-social views and attitudes amongst its audience.

On an immediate, practical and social level, the characters in the stories are engaged in working out their relations with themselves and with others. On a more abstract level, their behaviour is symbolic of the battle between good and evil in humans. In the world-view presented by the narrator/performer, the vices and desires of humans 
threaten to destroy the social order. The iintsomi underline the need for an ordered society, in which adherence to custom is emphasized as an effective means to maintain or to restore the cultural equilibrium (Scheub 82-84).

Scheub's literary theory is patterned on the ruling social paradigm of his time, namely structural-functionalism. Convincing as his wonderful academic prose may sound, the suggestion that traditional society operates as a structured, self-regulating and balanced organism (organic analogy), which is governed by the forces of solidarity and harmony (cultural homeostasis), has long been exposed in postmodern critique as a naive, if not a false reflection of reality. Nevertheless, I feel that the ideal of balanced and harmonious human relationships (as defined in the concept $u b u n t u$ ), could prove to be useful in a cultural analysis of traditional African folklore.

Contemporary writing on folklore, and on related forms of popular art, does not perceive of social strife as a stylistic tool. It interprets conflict in a more literal sense, as a reflection of real life conditions. Karin Barber's African Popular Culture (1997) presents a wide range of song texts, poetry, prose and visual art, which focus on the meaning of human conflict (migrants' songs from Lesotho, freedom fighters' songs from Zimbabwe, progressive popular theatre in Nigeria, Congolese anti-colonial painting etc.). Power, Marginality and African Oral Literature (Furniss and Gunner 1995) is written from a similar critical, progressive perspective. Folktales and other forms of orature, we learn in the introductory notes, can be powerful tools for the provoking, moving, directing, preventing, overturning and recasting of social reality (Furniss and Gunner $3-5,10)$. The authors of monographs of this kind maintain that human strife is unavoidably part of the human condition; that it is a useful conceptual tool for the understanding of social life, and that conflict is truly an almost necessary condition for social change.

On the home front, the authors of The Flamboyant Rooster (Kruger and le Roux 2007) share a similar conviction. They too assume that a socio-political perspective is the most appropriate means for the analysis of conflict in traditional narratives. Their discourse, though, is of a less radical nature than the one presented by Barber or Furniss and Gunner. They first point out to the reader, quite acutely, that the realm of indigenous storytelling offers "artistic maps of the human condition" and a "privileged view of human relationships". They then re-define the human universe of the stories as being controlled by class, seniority, physical power and the patriarchy (Kruger and le Roux 7). Gender relations, we are told, are often described in terms of violent, primordial images of male aggression. Men are said to be marauding animals, monsters that do not shy away from abduction, incest and rape (Kruger and le Roux 13).

On the other hand, it is proposed that the very same narratives that depict abuse and oppression also exemplify resistance against male and chiefly powers; aspirations for freedom; and the possibility of a new social order. Phrased differently, the tales become "a symbolic domain on which an unmistakably rebellious streak and a notion 
of freedom play out a struggle with dominance" (Kruger and le Roux 15). This "resistance ideology", the authors remind the reader, is not uniquely African. Rather it is "an enduring artistic objective and human endeavour" (Kruger and le Roux 7).

An interpretation of the average indigenous narrative, in terms of a "counter culture" of "resistance and rebellion", is perhaps a little overdramatic (well-intended as such an approach may be). Admittedly, a few of the stories within this (otherwise very exciting) monograph do depict social tensions of a more intensive kind. "The Lourie who was not a bird" (Kruger and le Roux 123-25) provides a case in point. It is interpreted by the authors as a warning, for the benefit of the youthful listeners, against paedophiles and rapists. The transgressor in this narrative is a handsome Lourie who seduces children at the river, takes them to his house, sexually abuses the oldest one, while holding the others captive. After a long period he returns the girls to their homestead, presenting himself as their saviour, and receiving a reward from the local ruler. Moral of the story: when young females or children are abused, it is of little use to complain to the chief, even more so when the culprit is living in the village of the ruler (Kruger and le Roux 124).

"The Lourie who was not a bird" appears to be a modified version of a most common story type, in which male predators meet with girls at the river, convince them to go for a walk and almost succeed in eating/killing them. The girls are then habitually saved by a little animal and returned home safely, where the hero is rewarded (e.g. Kriel 71). The moral of the story is usually explained as follows: little heroes succeed where others fail (or: respect the little ones); young girls should not trust men; and children should obey their elders or their senior siblings.

There are, obviously, particular reasons for the adaptation of "traditional" stories, and these should be looked for in historical, socio-economic and political circumstances. Modified versions can very often simply be explained in terms of culture change. Sabine Steinbrich's study of Lyela narratives in Furniss and Gunner's collection provides a very stimulating and historically contextualised analysis of intensified social conflict in African folklore.

Of the approximately one thousand folktales collected by Steinbrich, ten percent feature the King as the main protagonist (Furniss and Gunner 4-5). As a rule, narratives treat the King in a condescending way and depict a strong opposition between the people and their rulers. Steinbrich's research has established that the Lyela voice of cultural "resistance" in folklore disguises an underlying critique against French colonialism (92-93). Pre-colonial society was essentially acephalous and the stories express the memory of this autochtonous form of segmentary society. Steinbrich (101) explains how the French colonial administration introduced a "new indigenous" political hierarchy composed of village chiefs and three canton chiefs. This was resented by the colonial subjects, who turned the imposed chiefs into their favourite scapegoats in storytelling. All sorts of tensions in Lyela society were being projected 
onto them. At present, the main purpose of these narratives is to remind chiefs that in order to be popular, they have to rule justly.

Seemingly then, conflict theory offers a rather limited window on the theme of social discord in African folklore. A more inspiring understanding, I would like to suggest, comes, most surprisingly, from early missionary anthropology. Reverend Junod, the first author to take seriously note of the theme of social discord in folklore in southern Africa, was a humanist, an enthusiast and an enlightened student of human nature, indigenous culture and language. The "victory of the small over powerful enemies", he proposes in The Life of a South African Tribe (1927) typifies the Thonga/Ronga trickster animal folktales, as well as those stories "in which human beings, children, the miserable and the despised, triumph over their elders and those who hate them" (213).

In his understanding, the purpose of conflict narratives (most of which seemed to favour wisdom over brute force) is first and foremost, a moral one. Goodness is being rewarded, evil exposed. Far from trying to upset the existing social order, he reasons, the actions of the weaker party (the despised one, the insignificant little goat-herd, the son of the neglected wife) exemplify "the discrete protest" of weakness against strength, of the spiritual against the material, and perhaps even of the individual against the collective. Tales of conflict, Junod concludes, were meant to caution those in power (as in the saying: "A chief rules because of his people"). They are certainly not intended to subvert the principles of hierarchy or traditional authority, in which power was vested (223-24).

Remarkably, Ruth Benedict's study of Zuni mythology also identifies "the triumph of the despised and weak and previously worsted" as a "most popular theme" (in Mead 235). Benedict's splendid monograph on the art of storytelling in the largest pueblo of the South-West was published in two volumes (1935). In her analysis of Zuni narratives, she makes an important observation, which, in my opinion, is equally relevant to the analysis of children's stories in the southern African region. Benedict reminds the reader that some of the horrifying acts, committed by the protagonists, are not a reflection of Zuni custom or social life. In fact, they clearly contradict reality.

The abandonment of children at birth, for instance, features repeatedly in Zuni folklore. Violent action motivated by secret enmity is an equally recurrent theme. The former is simply unthinkable, whilst the latter constitutes gross exaggeration. Both types of stories are said to depict simple grudges, feelings of resentment and exaggerated fantasies of reprisal. Benedict indicates that social discord and the incidents of anti-social behaviour in Zuni tales serve psychological purposes. In the final analysis, she explains, their chief function is to teach people exactly the opposite of what they depict, which is to love one another (in Mead 232-35). 


\section{First reading: cultural analysis}

The following eight narratives describe gender opposition. They have been selected to provide examples of the different variations on the theme of "conflict" between men and women. The selected tales exemplify the full range of shades of intensity of conflict. Five stories have been recorded in the field; the three remaining ones belong to published collections. The discussion combines the comments, perspectives and interpretations of the narrators and other female elders, with the insights that the author has gained from studying a variety of cultural materials, amongst Venda, Northern Sotho and Tsonga speakers, over the past three decades. A sample of more than hundred folktales was collected in the Vhembe district between 1995 and 1998, and again between 2001 and 2003. The recording of narratives started off as an unrelated side project when doing doctoral research. Most of the narrators and discussants were female pensioners. Occasionally old men joined in the discussion, but the data presented here basically constitute women's perspectives.

Storytelling in the province, as elsewhere in South Africa, is a fading art. Although anybody could tell a story, most women agreed that in the past, the task of entertaining the children with traditional narratives was often left to an expert in the village. Only a few of the women who volunteered to present a narrative claimed to have been regular storytellers. The interpretative sessions included, in addition to the narrator, some of her neighbours and friends. The author focused on the common ground reached by the commentators, rather than on the differences of opinions which the tales occasionally elicited, presumably on account of the individual temperaments and life experiences of particular discussants. The three published folktales were also discussed in the field. All the texts are abridged versions of the original tales.

That at least some of the stories have been passed on, relatively unchanged, for several generations, is demonstrated by the published version of tale 4 , which was recorded by the anthropologist Gerard Lestrade more than sixty years ago. That narratives were shared across ethnic boundaries, is exemplified by well-known stories like "The girl made of cow dung" (Aschwanden; Kruger and le Roux). The headings of the recorded tales in this essay were agreed upon with the narrators (traditionally folktales featured no titles).

\section{Tale 1 "The clever little girl"}

\section{Narrator: Vho-M. Ratshikhopa, Tshilamba, 2003; original in Tshivenda.}

Four girls from a certain family decided to collect wood. Their little sister decided to accompany them. They instructed her to return home, but she refused. They walked and reached a junction. They argued which road to take. They chose a path and the little girl advised them to turn back. Again they refused. They walked and noticed a bird. It sang: "Ndiko, ndiko, ndarieni hayani!" "Ndiko, ndiko, let us go home!" The girls replied: "Let us go home!" They followed the bird and walked for a long time. 
Finally they reached a house. In that house lived a man and a woman. They fed the girls with lies. The little girl refused to eat. In the middle of the night, the little girl suddenly woke up and found the woman holding a big knife. She sang: "Meat! Intestines! Liver!" The little girl waited until the man and woman had left the house and then woke up the others. They put down wooden stamping blocks on the floor, covered them with blankets and ran. When the man checked the girls he realised that they had escaped. He called the other cannibals (malavhathu). The little girl asked a tree to pick them up. The cannibals fetched their machetes [to cut the tree]. The girls ran off again. A frog was asked to swallow them. When the cannibals returned with their machetes, they asked the frog if it had seen the girls. It replied: "No!" They kicked the frog with the girls across the river. This is where the story dies.

In the fantasy world of this Tshivenda story (and many similar dzingano), the normal social hierarchy is turned upside down and the youngest girl is portrayed as the leader. The bigger sisters are duped time and again. They choose the wrong path. They follow the enchanting song of the malicious bird. They enter the homestead of cunning strangers and "eat" their lies. They seem ignorant of the threat posed by man-eaters who move around at night. Their clever little sibling, on the other hand, can clearly distinguish between good and evil. It is her sound judgement and moral behaviour that rescue the helpless sisters. She is the heroine of the story and the narrator uses her as role model for the benefit of the audience of little listeners.

Those who participated in the discussion of the folktale, concurred that the little girl depicted the ideal image of "the moral girl". Some added that in real life the youngest would probably not be the cleverest, but that the story was meant to entertain and to inspire the little ones.

Tale 2 "A man and his wife during the year of hunger"

Narrator: Vho-N. Mulaudzi, Tshimbupfe, 1998; original in Tshivenda.

It happened during the time of starvation. Day after day, a man and his wife were troubled by hunger. Then, the wife came up with a plan: she prepared a meal from the husks of [the previous harvest of] maize. The husband refused to eat: "I am a big person (muhulwane). Give the food to the little ones and I will lick the knife and sleep!" Every day he said the same thing. Every day he went out to look for food [for his family] and returned empty handed. At home he refused mufumbu, the porridge made of husks. He had hidden a big pot of milk, from which he drank daily with a hollow reed. After some time, the wife was getting worried. How would her husband survive without eating? She found the pot and replaced it by one filled with a mixture of water and ashes. When the man drank from this pot he coughed and coughed. He was terribly ashamed, when the wife showed him the 
pot of milk. From then onwards, he joined in the eating of mufumbu. Salungano! The end.

"A man must work for his food and share it with his wife and children!" was the general consensus of the discussants of this tale. The story is set during a drought, a time of crisis, when the normal rules of communal sharing are expected to be applied with more rigour. Milk is considered to be a treat. Mufumbu, maize husks, on the other hand, are used to feed pigs and chickens.

The husband or father who secretly enjoys the best food in times of starvation, is not only selfish, he is cruel. This particular man is also a hypocrite. He pretends to give his share of the evening meal to the children. He says he will "lick the knife" ( $u$ nanzwa banga), meaning: he will scrape the leftovers and remain hungry. He calls himself muhulwane, a "big person", a leader, the head of the family, the man of the house. His behaviour, in contrast, is childlike and shameful. A person in a senior position, the narrator reminds the audience, does not just enjoy rights and privileges. He must be mindful of his duties too.

\section{Tale 3 "The man who changed into a baboon"}

Narrator: Vho-M. Mudau, Tsianda, 2003; original in Tshivenda.

A man and his wife used to quarrel a lot. They built a small shelter in a field near the mountain. They put their child in it to guard the summer crops. The man thought: "The maize is mine, so I can eat it alone". He walked to the field, changed into a baboon and started eating. The child tried to chase the baboon, but he failed. The baboon sang and ate: "I eat my maize. I dance and leave. I leave for the mountain. I run away from that talking mother of yours. She talks early in the morning. She talks in the evening". It changed back into a human. The man went home, where he sat in the shadow of his house. The child arrived and told the mother about the baboon. When the wife offered the man food, he refused: "Don"t bother. I had [sorghum] beer". The next day the wife instructed her son to take the dog to the field and chase the animal. The man changed into a baboon. The dog was sent on him. But the baboon was too big and the dog ran away. The baboon ate and sang its song: [...]. In the evening the child returned home and told his mother that he was not going to go to the field again. He was afraid of the baboon. The woman asked her husband to solve the problem. He replied: "I am too lazy to guard the field". The villagers then decided to kill the baboon. They waited for the animal to arrive and attacked it. Just before it died, the baboon changed back into a human. They tried to help the man, but he died.

Husbands, it was suggested by several discussants, can change after a few years of marriage. They can become dangerous. The baboon is a metaphor for wild, harmful 
and irresponsible behaviour. Marriage partners, others emphasized, must be selected with great care. This category of narrative, some insisted, was created in order to caution young people and their parents, "to prevent mistakes and avoid people's lives to be destroyed".

The husband who secretly changed into a baboon was clearly unhappy with his wife: "She talks early in the morning. She talks in the evening". However, the story does not mention the cause of marital strife. The listeners are merely told, in the opening lines, that this particular couple has developed a habit of swearing at each other (u semana). Female discussants explained that they had been taught, as young girls, not to argue back ( $u$ tatisa) when being reproached by their husband. This was considered to be disrespectful and provocative, by both men and women. However, the real issue, the same informants were quick to point out, was the fact that this particular husband had turned into a selfish man (munna wa tseda), i.e. a man who likes to eat alone, who does not share. He secretly stole food from his family, and was, therefore, no longer considered to be a real husband and father.

Tale 4 "The husband and wife who fought about a non-existing goat" Narrator: Vho-E. Netshiya, Tshisaulu, 2001; original in Tshivenda.

An almost identical story was published sixty years ago by Lestrade (24-25). It happened one day that a man talked to his wife in the field. They had no children and guarded the crops by themselves. He suggested that it would be a good thing if they sold some of the harvest and bought a female goat. The wife would become the owner of this goat. It would give birth to a little one, and the man would look after it. The little one would provide a carrying skin for the couple's first baby. The wife agreed happily and remarked that goat milk would nourish their child well. The husband protested. He wanted the milk for his little goat so that it would grow strong. The woman was shocked and accused the husband of withholding the food from her child, for the benefit of a goat that had plenty of grass to eat! The husband, in turn, could not believe that his wicked wife was going to let his little one die, whereas she had her own milk to feed the baby. And so the fight deteriorated until they ended up hurting each other. The woman fled to her people and left the man without a wife.

This folktale, very creatively, illustrates how a small argument between people can grow bigger and have a disastrous ending. The emotions of both partners progressively change from love and concern to anger and envy. Although husband and wife are represented as equally silly in fighting about some imaginary events—-the discussants agreed with one another-the husband is blamed for initiating the argument. In the end he is left without somebody to care for him: he is rightfully punished for his selfish thinking. It is dangerous for married people to argue endlessly, everybody 
present agreed. The fact that being a married adult requires consideration for others and self-discipline, is equally well demonstrated by the following tale.

\section{Tale 5 "Hearts which are alike"}

\section{Recorded by Lestrade (25-26); original in Tshivenda.}

There once was a terrible famine. A man and his wife lived unhappily, accusing each other of depleting their food supplies. This man was a great hunter of guinea fowl. Even if meat was plenty, they continued to quarrel over food. The man instructed his wife to cook one of the animals. She cooked it and replaced it by another, so that she could eat the first one whilst hiding behind a large storage bin. The man, thinking that his wife had gone out, replaced the guinea fowl in the pot by a third one. He decided to eat his fowl behind the very same storage bin. There he found his wife. "Our hearts are alike" he remarked, and they decided to go and eat together outside. They stopped fighting. They spent the rest of the famine foraging together for something edible. And the land became at peace and prosperous again.

This is probably as much a tale about sexual opposition, as it is one against! It develops in a different direction from the previous one. It clearly does not privilege a feminine perspective in the same way as the other stories do. It starts off with a miserable, divided couple bickering over food (although they have relatively plenty of it), and ends happily with the same pair facing the challenges of the drought together. I have presented this published tale to some female elders for discussion, during several of my field trips.

Hiding food during times of hardship, it was suggested once more by the discussants, is considered immoral (as in tale 2), and so is the selfish act of eating alone (u tseda; see tale 3).

The narrative, I would like to add, also exemplifies the fundamental belief in the close association between natural calamities and moral life. The grain bins, we are told, were filled with food when there was peace in the land. In contrast, the narrator describes how conflict becomes a ruling force during times of famine. There is, in other words, a mystical connection between the natural and the social universe, between prosperity and sound human relations. The moral of the story is obvious: marital strife, like the drought, is conceived of as an anomaly, a disturbance in the normal order of things.

Tale 6 "The woman who killed the big snake"

Narrator: Manhi-M. Hlongwane, Nghomunghomu, 2001; original in Xitsonga.

In the village of Nghomunghomu lived a man by the name of Mkhacani. He left home in order to hunt in the nearby mountains. He loved game hunting for the 
taste of the meat, especially lion's meat. There he was attacked by Ximemene, a Snake that had killed many. It enjoyed hiding high up in a tree and attacked hunters from there. It grabbed its victim by the head and crushed the skull in order to get to the brain. The snake assaulted Mkhacani from its hiding place in the tree. The snake killed the famous hunter. The wife reported Mkhacani's death to the chief, who called a meeting. Strong men were sent to the mountain. They walked whilst singing: "Mee, Mee, Mee, Mee, Sombelisa [...]". The huge snake scared the men back to the village. The wife was angry and made a plan. She prepared a pot of hot soft porridge. She walked to the mountain, balancing the pot on her head, singing the song: "Mee, Mee, Mee, Mee, Sombelisa [...]". The snake prepared for the attack and the woman continued walking and singing: "Mee, Mee, Mee, Mee, Sombelisa [...]". The snake tried to grab her head, but landed in the hot porridge and died. The woman was honoured by the chief and villagers.

Women enjoyed listening to this story, as the narrator basically suggested that a woman can succeed where men have failed. The tale appears to gnaw at the very foundations of man's assumed superiority: his virility. Mkhacani was not just an average hunter or an ordinary man. He was an extraordinary hunter and the bravest of men, who loved hunting the most ferocious beast, the lion. Similarly, the king did not send ordinary men to fight the snake; he sent the strongest of the district. Mkhacani's wife, on the other hand, not unlike her husband, decided to face the monster without the help of anybody. And unlike the brave warriors, she did not run back to the village, after she found her opponent. Neither did she use a spear or a battle axe. She went out to kill the serpent armed with nothing more than a simple kitchen utensil (and her mind). So much for virility and the might of men, the female elders commented! This tale echoes Junod's acute observation that many stories exemplify how wisdom can defeat physical strength.

\section{Tale 7 "The girl who defeated the drought"}

Recorded by Scheub (406-11); original in isiHlhubi.

The heavens became dry. Rivers and wells disappeared. One day, a little girl climbed the mountain in search of water. She met with a Great Bird. The Great Bird gave her water and instructed her not to tell anybody. Back in the village, they asked her if she had been given something to drink. She said: "No!" The following day she went back to see the Bird, was cautioned, received water and returned home. There she was asked whether she had found water. She replied: "No!" After her third visit to the Bird, and another inquiry, the men of the village called for a meeting. They scolded her and forced her to divulge the secret. She took them to the mountain. They shot the Bird. Water gushed out from its body and rivers and springs were filled. And so the drought was defeated. 
I have discussed this published tale with women on more than one occasion. In real life, little girls, are not allowed to venture far from the village, the discussants reminded me. They certainly do not go about hiking in the mountains without any escort. Moreover, real children are terrified of big, dangerous animals. They cannot face, understand or challenge the mysterious natural and supernatural forces that threaten society. In the fantasy world of folklore, things are different. The little ones become heroes. Unlike their "real" counterparts they behave independently. They display wisdom and confidence, and act fearlessly. The analysis could easily end here, if it wasn't for the fact that, in the not so distant past, children were entrusted with important ritual tasks and, more intriguingly, birds were symbolically connected to rain, and women.

The fact that a little girl receives water from the Great Bird, and eventually helps the whole village to defeat the drought, is probably inspired by the cultural practice of using small children to plead with the ancestors and other supernatural forces, on behalf of the community, during a variety of rituals. Among the Venda, e.g. young girls of royal descent were selected by a diviner in order to prepare beer for the most important of sacrificial rites (van Warmelo 153-57). Moreover, small children of both sexes used to play a key role in the rain making rituals of Venda, Lovedu, Northern Sotho and Eastern Tswana communities (Schapera 97).

On the other hand, as one of the discussants pointed out, The Great Bird is somewhat reminiscent of the belief in a mysterious species of birds that causes rain, lightning and thunder (Dederen and Short). "We used to honour a Great Bird in the Sungwi" another added. The Sungwi or Musevhetho was a circumcision school for Venda girls. The mystic association between sacred categories of Birds and womanhood is most obviously manifested in the girls' circumcision schools among the Venda and Lovedu (the Sungwi and Byali; van Warmelo 79-103; Krige 126-40). These rites of passage were organised around the central "mystery" of a Great Bird, the ruling spirit of the school. Seemingly, birds and women were symbolically connected through the concept of fertility. Supernatural birds inhabit the skies that produce rain and help crops, animals and humankind survive. Women produce children and safeguard the continuity of human existence. Both skies and wombs, the mysterious loci of metaphysical life giving forces, were identified in religious thought, throughout southern Africa, as being of primary cosmological significance.

\section{Tale 8 "Dondodzi"}

\section{Collected by Krüger (11-12); original in Tshivenda.}

Dondodzi was a lazy girl. She wanted to marry a man who did not eat porridge, and whose only food was the smoking of hemp. Many fine suitors came, but all of them ate porridge. Her younger sisters got married. Finally two young men arrived. They were unknown to anybody. They lived off hemp. Dondodzi agreed to marry 
one of them. Girls from all over the district accompanied her to the home of the groom. During the long journey, all girls turned back, one by one. Only her cousin Tshiwela remained. They finally arrived. In the afternoon both men went hunting. They ate the meat and threw the bones behind the hut. During the night the two girls could hear how the bones were being gnawed. They lived there for a long time. One day the young men told the girls to shave their hair and prepare to be introduced to the parents-in-law. A Great Bird arrived at the hut, asking Dondodzi for food. She refused. Tshiwela agreed to feed the Bird. The Bird showed her how hyenas were approaching. The Bird threw the hair of both girls around the hut. The hair talked to the hyenas whenever they called for the girls. Eventually the beasts got tired. The Bird flew the girls back home and landed on a big tree in the courtyard of the men. The king had an ox slaughtered for the Bird. The Bird left after the feast was ended.

Dondodzi, I was told by several discussants, has no interest in cooking, one of the basic domestic tasks of a wife. She represents the young girl who is unfit for marriage, and therefore is destined not to get a (decent) husband.

The young man who proposes to marry her, and his friends, belong to a gang of shape shifting men, who are planning to abuse both Dondodzi and her cousin. If it wasn't for Tshiwela, Dondodzi would have died a certain death. Tshiwela is the one who feeds the Great Bird and pleads for both of them to be rescued. The Great Bird saves the women with its magic and flies them back home.

In this tale a magical Bird protects and saves two young women from male abuse. The symbolic association of the Bird with womanhood is emphasized by a small but significant detail: it places Tshiwela on an ant heap so that she can clearly see the approaching pack of hyenas (i.e. the males that threaten womanhood). The ant heap, in Africa, is a common metaphor for female fertility. The fact that the Bird reunites the girls with their families in the public meeting-place, i.e. in the courtyard of the men, clearly constitutes an additional reference to sexual opposition in the narrative.

\section{Second reading: between submission and subversion}

When I first analysed the wider corpus of collected and published stories in order to select some for presentation in this essay, I soon realized that the theme of human strife, and more particularly of gender opposition, was depicted in varying degrees of intensity. More importantly, in many stories, even when manifestly present, conflict between the sexes was not necessarily the dominant theme.

Stories often were multivocal in that they highlighted a number of issues. Phrased differently: the narrator may relate how men are being undermined, exposed or tricked by women, but none of this was deemed more relevant (in the eyes of the narrator and 
the listeners) than the issues of respect, generosity, obedience, dignity, responsibility, industriousness, tolerance and wisdom. I would therefore agree with Junod (and many of the discussants) that a "code of elementary morals" dominated both the communicative efforts of the narrators and the didactic purpose of the indigenous narratives (222). This should not surprise us, since folklore formed part and parcel of the "indigenous curriculum" of the wider processes of enculturation.

In the particular sample of eight tales under discussion here, the narrators primarily used their craft to remind young listeners (female and male) that the elders knew best; that disobedience would be punished; that the sharing of food was mandatory; that selfishness and hypocrisy were shameful, and that laziness was self-destructive.

At times the narrative voice explicitly discouraged sexual opposition. In the story about the fight over an imaginary goat, the narrator emphasized the absurdity of (certain forms of) marital strife. The creator of "Hearts which are alike," similarly denounced domestic conflict. Children's stories, in my understanding, constituted a first organised attempt, on behalf of society, at preparing youths for marital unison. The second attempt was made during puberty initiation. This continuity between children's storytelling on the one hand, and ritual pedagogy on the other, I believe, has generally been overlooked in the anthropological literature, possibly because the didactic purpose, format and context of both institutions appear to be radically different. For a long time, anthropologists considered storytelling to be primarily a form of entertainment, and therefore not much of an intellectual challenge. Initiation, in contrast, was presumed from the beginning to be a fertile ground for the analysis of symbolic thought and action. Besides, how could storytelling for children possibly relate to initiation, when the latter was organized to "wash away childhood", i.e. to mark the break with childhood?

On closer scrutiny, the fantasy world of folklore also mediated serious social issues from the real world. Rites of passage, on the other hand, featured a strong and functional element of play. Ultimately, both social realms were geared towards the realisation of marriage. Matrimony was considered to be of paramount importance in traditional societies. The institution of marriage facilitated human procreation, human survival and the continuity of a particular family or lineage. Therefore, the complementarity of the sexes was the single most important theme in the symbolic discourse of folklore. It also featured centrally in the dances, mimes, songs, rites and ceremonies of ritual pedagogy. For example in the didactics of the Venda domba, a traditional "finishing school" for male and female initiates, the concept of sexual unison - the complementarity of wife and husband—was referred to as Mudzimu, the "god" of the initiation school. I am of the opinion that storytelling was, at least partially, shaped by the same "god" of complementarity. As such, the narrator was expected to promote a balanced form of interaction between marital partners, rather than their opposition. 
The numerous adventures of three or four maidens, accompanied by their little sibling, cautioned young girls against the aggression of men-beasts. However, these stories did not preach subversion or the rejection of the patriarchy. Most informants identified the moral behaviour of the little girl — not the victory over evil manhoodas the central idea. Furthermore, these were stories about bad girls, almost as much as about bad boys. The image of the immoral girl was most clearly developed in the tale of lazy Dondodzi. The narrator made mention of many fine young men who came to propose marriage. Yet Dondozi chose the wrong suitor.

In the more "radical" stories, we found wives who had their shape shifting husbands exterminated. Note, however, how these mean husbands weren't actually killed by their "rebellious" wives, and, furthermore, how they were portrayed, partially at least, as the victims of their own misbehaviour. Their threatening attitude was an issue which affected the community at large. Neighbours and fellow villagers were called in to take care of the problem. In the case of the evil baboon (in tale 3), the very same people who tried to kill the animal were also described by the narrator as attempting to save the human being (who had changed into a baboon).

When men do not get what they want, some women explained, they start behaving irrationally. The baboon-man could not stomach the criticism of his wife, hence his idle, selfish and irresponsible behaviour. To a certain extent, he had turned upon himself. He wasn't really "evil", I was assured. His behaviour was that of a spoilt child rather than of a monster.

The woman who killed Ximemene, the terrible Serpent, challenged the virility of the brave men selected by the village council. She succeeded where men have failed. Yet, she did not defy her husband, the great lion hunter. Rather, she vindicated his death. In using practical wisdom instead of physical strength, she did, in any case, not compete with the masculinity of hunters or warriors.

It appears, then, that sexual opposition was, generally, not a matter of subversion or rebellion. Rather, it was subtle in nature. This is not to say that rural women passively accepted the ruling patriarchy, or that a more active form of resistance is entirely absent from African folklore. In the narratives known to me, nonetheless, the female voice does not call for social disruption. Instead, women simply seem to caution future brides; expose the weaknesses of men; question and casually ridicule virility, and remind husbands of their duties and of the social limits within which male authority is supposed to function.

Finally, the magical powers of the supernatural birds in tales 1, 6 and 7, I believe, were more than just stylistic tools, used by the narrator to capture the attention of the audience or to enhance the experience of the young listeners. Bird-controlled magic for the benefit of female protagonists, in my opinion, expressed, declared and celebrated the true essence of womanhood, the real power and the ultimate secret of women: human fertility. The birds represented the life-giving forces; the control 
women yielded over these forces; and the protective strength they derived from it. Female fertility symbolism, of course, was more prominent in the initiation rites for young women, where it played a more active part. Nevertheless, informed by extensive research on ritual pedagogy in southern Africa, I can confidently say that it wasn't used to confront masculinity in a threatening, let alone in a subversive way. In fact, both male and female initiation lodges made use of subtle and sophisticated, indirect means of "confrontation".

To sum up, storytelling, in the not so distant past, was one of several cultural means, used by women to construct a relative autonomous space for themselves. Women have "resisted" patriarchal ideologies through a vast array of symbolic and tangible means: taboos, vernacular architecture, ritual pedagogy, iron smelting and the adornment of the body, to mention only a few. The female space was a proud, dignified and proactive entity. Sadly, it was also a delicate one. It has been invaded, harassed and partly destroyed, under the duress of the acculturative forces that have annihilated the social fabric that supported it. I would like to suggest, by means of conclusion, that rural women's subtle and symbolic modes of opposition to men, constitute an authentic and a worthwhile subject of study for anybody interested in an interpretive window on culture or in a humanist form of social science.

\section{Works cited}

Aschwanden, Herbert. Karanga Mythology. Gweru: Mambo Press, 1989.

Barber, Karen (ed.). Readings in African Popular Culture. London: James Currey, 1997.

Benedict, Ruth. Zuni Mythology (2 vols). New York: U California P, 1935.

Dederen, Jean-Marie \& Vincent Short. "The Birds of Heaven." Quagga 20/21 (1988): 5-10.

Furniss, Graham and Liz Gunner, Liz. Power, Marginality and African Oral Literature. Cambridge: Cambridge UP, 1995.

Junod, Henri A. The Life of a South African Tribe. Nondon: Macmillan, 1927.

Krige, Eileen. The Realm of a Rain Queen. Oxford: Oxford UP, 1943.

Kriel, Abraham. An African Horizon. Cape Town: Permanent Publishing House. 1971.

Krüger, Franz. "Venda-Märchen." Zeitschrift für Eingeborenen Sprachen 23/24 (1933): 11-12.

Kruger, ,Jaco and Ina le Roux. The Flamboyant Rooster and other Tshivenda song stories. Potchefstroom: School of Music, North West U, 2007.

Lestrade, Gerard P. Some Venda Folk-Tales. Cape Town: Lovedale Press, 1949.

Mead, Margaret. An Anthropologist at Work. Writings of Ruth Benedict. Boston: Houghton Mifflin. 1966. Schapera, Isaac. The Bantu-Speaking Tribes of South-Africa. Cape Town: Maskew Miller, 1956.

Scheub, Harold. The Xhosa Ntsomi. Oxford: Clarendon Press, 1975.

Stayt, Hugh A. The Bavenda. Oxford: Oxford UP, 1931.

Steinbrich, Sabine. "Images of the powerful in Lyela folktales." Eds. Graham Furniss and Liz Gunner. Power, Marginality and African Oral Literature. Cambridge: Cambridge UP, 1995: 92-108.

Van Warmelo, Nicholas J. Contributions towards Venda History, Religion and Tribal Ritual. Pretoria: Government Printers, 1932. 